\title{
Functional characterization and localization of AQ P3 in the human colon
}

\section{Silberstein, A. Kierbel, G. Amodeo, E. Zotta, \\ F. Bigi, D. Berkowski and C. Ibarra}

\author{
Laboratorio de Fisiopatogenia, Departamento de Fisiología, \\ Facultad de Medicina, Universidad Nacional de Buenos Aires, \\ Buenos Aires, Argentina
}

\section{Correspondence \\ C. Ibarra \\ Departamento de Fisiología \\ Facultad de Medicina, UBA \\ Paraguay 2155, 70 piso \\ 1121 Buenos Aires \\ Argentina \\ Fax: + 54-1-963-6287 \\ E-mail: ibarra@fmed.uba.ar \\ Part of these data were presented at the International Symposium of the Molecular Physiology of W ater Transport, Paris, France, April 27-30, 1997. \\ Research supported by the Universidad de Buenos Aires (TM23) and the Consejo Nacional de Investigaciones Científicas y Técnicas (PIP No. 867/98).}

Received February 12, 1999 Accepted July 26, 1999

\section{Abstract}

Water channels or aquaporins (AQPs) have been identified in a large variety of tissues. Nevertheless, their role in the human gastrointestinal tract, where their action is essential for the reabsorption and secretion of water and electrolytes, is still unclear. The purpose of the present study was to investigate the structure and function of water channels expressed in the human colon. A cDNA fragment of about 420 bp with a $98 \%$ identity to human AQP3 was amplified from human stomach, small intestine and colon by reverse transcription polymerase chain reaction (RT-PCR) and a transcript of $2.2 \mathrm{~kb}$ was expressed more abundantly in colon than in jejunum, ileum and stomach as indicated by Northern blots. Expression of mRNA from the colon of adults and children but not from other gastrointestinal regions in Xenopus oocytes enhanced the osmotic water permeability, and the urea and glycerol transport in a manner sensitive to an antisense $\mathrm{AQP} 3$ oligonucleotide, indicating the presence of functional AQP3. Immunocytochemistry and immunofluorescence studies in human colon revealed that the AQP3 protein is restricted to the villus epithelial cells. The immunostaining within these cells was more intense in the apical than in the basolateral membranes. The presence of AQP3 in villus epithelial cells suggests that AQP3 is implicated in water absorption across human colonic surface cells.

\section{Introduction}

Approximately 9 liters per day of water are involved in the digestion process and due to the great absorptive capacity of the intestine, only 0.2 liters are excreted with the stool (1). The opposite can also occur, i.e., the small and large intestine can secrete large amounts of water in the presence of toxins or endogenous secretagogues $(2,3)$. It is generally accepted that these important fluid trans- fers are associated with salt reabsorption or secretion. Nevertheless, it is still a subject of controversy whether the absorptive processes are located in the surface (and villus) cells, if the secretory processes are located in the crypt cells $(4,5)$ and if the transport-associated water movements are transcellular or paracellular $(6,7)$.

The recent characterization and cloning of aquaporins (AQPs) have introduced a new approach to this problem. These structures 
are found in those membranes which present high osmotic permeability and there is general agreement that the presence of functional AQPs in an epithelial barrier strongly indicates the existence of a transcellular route for the water transfers (8-10). In the gastrointestinal tract, physiological and biophysical studies have provided evidence against the expression of water channels in the epithelial cells from the stomach (11) and jejunum (12) or in Caco-2, a cell line derived from human colon carcinoma (13). In these cases, the paracellular route has been proposed as the main route for the transportassociated water transfer.

Alternatively, the presence of functional water channels has been postulated in rabbit rectal epithelium (7) and AQP expression in stomach, small intestine and colon has been reported in studies using Northern blots and immunolocalization (14-20).

In the present study we show that when mRNA from different sections of the gastrointestinal tract was injected into Xenopus oocytes, only the portion corresponding to the colon expressed functional AQP3 which are more intensely localized in the apical membranes and less intensely localized in the basolateral membranes of villus epithelial cells.

\section{Material and Methods}

\section{Patient specimens}

The surgical specimens used in this study were obtained from 16 patients from the Hospital de Gastroenterología "Dr. Bonorino Udaondo", Hospital de Niños "Dr. Pedro de Elizalde" and Hospital Israelita. The clinical conditions requiring removal of sections from stomach, small or large intestine in these patients were different carcinomas for adult specimens $(\mathrm{N}=14)$ and Hirschsprung's disease $(\mathrm{N}=2$, ages ranging between 3 and 7 years old) in the case of children's specimens. Twenty-four hours prior to surgery, 25 to $40 \mathrm{ml} \mathrm{kg}$ body weight $^{-1} \mathrm{~h}^{-1}$ of an isos- motic lavage solution containing $25 \mathrm{mM}$ $\mathrm{NaCl}, 40 \mathrm{mM} \mathrm{Na}_{2} \mathrm{SO}_{4}, 10 \mathrm{mM} \mathrm{KCl}, 20 \mathrm{mM}$ $\mathrm{NaHCO}_{3}$ and $60 \mathrm{~g} / 1$ polyethylene glycol (PEG) was orally administered to the patients until the fecal discharge was clear and free of solid matter. This solution was reported to cause no net water or ion movement across the gut (21). Tissues used for these studies were taken from macroscopically normal areas within the "safety margin" from the pathological affected tissue. Segments were transported in ice-cold high $\mathrm{K}^{+}$-Ringer solution to the laboratory and processed within $2 \mathrm{~h}$ of excision. The high $\mathrm{K}^{+}$Ringer solution containing $120 \mathrm{mM} \mathrm{KCl}, 10$ $\mathrm{mMNaHCO}_{3}, 1.2 \mathrm{mM} \mathrm{MgCl}_{2}, 1.2 \mathrm{mMCaCl}_{2}$, $1.2 \mathrm{mM} \mathrm{K}_{2} \mathrm{HPO}_{4}, 0.2 \mathrm{mM} \mathrm{KH}_{2} \mathrm{PO}_{4}$, and 25 $\mathrm{mM}$ glucose preserves the transport function across the colonic epithelial cells (6). This protocol was approved by the Ethics Committee of the Gastroenterology, Children and Israelita Hospitals.

\section{mRNA extraction}

The intestinal specimens were washed with $0.9 \% \mathrm{NaCl}$, opened along the mesenteric border and everted with a forceps on an iced Petri dish. The mucosa and submucosa were stripped from the muscular layers and underlying tissue and the mucosa was gently scraped with a glass microscope slide. The scrapings containing $1 \mathrm{~g}$ of epithelial cells were immediately suspended in $10 \mathrm{ml}$ of $4 \mathrm{M}$ guanidinium thiocyanate, $25 \mathrm{mM}$ sodium citrate, $\mathrm{pH} 7,0.5 \%$ sarcosyl and $0.1 \mathrm{mM} \beta$ mercaptoethanol. The mixture was homogenized for $30 \mathrm{~s}$ on ice using an Ultra-Turrax T25 blender at maximum speed. An equal volume of water-saturated phenol, 0.1 volume of $2 \mathrm{M}$ sodium acetate, $\mathrm{pH} 4$, and 0.2 volume of chloroform were added and vortexed. The final suspension was cooled on ice for $15 \mathrm{~min}$ and then centrifuged at $10,000 \mathrm{~g}$ for $20 \mathrm{~min}$ at $4^{\circ} \mathrm{C}$. The supernatant was precipitated with ice-cold isopropanol and eventually dissolved in Tris/EDTA buf- 
fer, $\mathrm{pH}$ 7.4. RNA purity and concentration were assessed spectrophotometrically. Oligo $(\mathrm{dT})^{15}$-cellulose columns (Sigma Chemical Co., St. Louis, MO, USA) were used to isolate mRNA. The mean yield of mRNA was approximately 1 to $5 \mu \mathrm{g}$ for each specimen. RNA samples were stored at $-80^{\circ} \mathrm{C}$ until the time for use.

\section{RT-PCR assay}

Reverse transcription was performed on $5 \mu \mathrm{g}$ of total mRNA from human colon mucosa using Moloney murine leukemia virus reverse transcriptase (Gibco, BRL, Gaithersburg, MD, USA), oligo (dT) ${ }^{15}$ primer and $400 \mu \mathrm{M}$ of each deoxyribonucleotide triphosphate (dNTP) for $60 \mathrm{~min}$ at $37^{\circ} \mathrm{C}$. PCR $\left(30\right.$ cycles at $94^{\circ} \mathrm{C} 60 \mathrm{~s}, 50^{\circ} \mathrm{C} 60 \mathrm{~s}$ and $72^{\circ} \mathrm{C} 60 \mathrm{~s}$, followed by a final extension of $10 \mathrm{~min}$ at $72^{\circ} \mathrm{C}$ ) was carried out using $5 \mu \mathrm{M}$ of two degenerate primers designed on the basis of highly conserved regions (NPA box) in the aquaporin family.

The sense [5'-CAC(C/T)T(G/C)AACCC (A/T)GC(G/T)GT(C/G)AC-3'] and antisense [5'-AAA(G/T)TC(C/A)CG(A/G)GC(T/ A)GGGTT-3'] oligonucleotide primers corresponded to the nucleotides coding for amino acids 73-78 and 192-199, respectively, of the AQP1 sequence (X70257/S52660), and to amino acids 81-86 and 215-222 of the AQP3 sequence (D17695/D25280). Agarose gel electrophoresis of the RT-PCR products showed a 420-bp band that was cloned in the pGEM-T vector (Promega Corp., Madison, WI, USA) and the fragment was sequenced using the $f$ mol kit (Promega). RT-PCR was also assayed with adult stomach, jejunum, ileum, and children's distal colon mRNA using $2 \mu \mathrm{M}$ of the specific sense [5'-CC TGAACCCTGCGGTGACC-3'] and antisense [5'-GGCATAGCCGGAGTTGAAGC3'] oligonucleotide primers based on the RTPCR product from colon. The protocol was 30 cycles at $94^{\circ} \mathrm{C} 60 \mathrm{~s}, 55^{\circ} \mathrm{C} 60 \mathrm{~s}$, and $72^{\circ} \mathrm{C}$ $60 \mathrm{~s}$, followed by a final extension of $10 \mathrm{~min}$ at $72^{\circ} \mathrm{C}$. PCR products were cloned and sequenced as described before.

\section{Northern blotting}

About $10 \mu \mathrm{g}$ of each total RNA was electrophoresed on a denaturing $1.4 \%$ agarose gel containing $2.2 \mathrm{M}$ formaldehyde. One part of the gel was stained with ethidium bromide to evaluate the intensity and quality of $18 \mathrm{~S}$ and $28 \mathrm{~S}$ ribosomal bands for the different RNA samples. The other part was transferred to a reinforced nitrocellulose membrane (BAS85, Schleicher and Schuell, Dassek, Germany), fixed for $2 \mathrm{~h}$ at $80^{\circ} \mathrm{C}$ and prehybridized for $4 \mathrm{~h}$ at $42^{\circ} \mathrm{C}$ with a standard prehybridization buffer containing $50 \%$ formamide, $5 x$ SSC, $0.5 \%$ SDS and salmon sperm DNA $(100 \mu \mathrm{g} / \mathrm{ml})$ and hybridized overnight at $42^{\circ} \mathrm{C}$ with $10-20 \mu{ }^{32} \mathrm{P}$ $\mathrm{dCTP}$ labeled probe diluted in a fresh $5-\mathrm{ml}$ aliquot of warmed prehybridization buffer. Blots were then washed twice for $5 \mathrm{~min}$ in $2 \mathrm{x}$ SSC, $0.1 \%$ SDS at room temperature followed by $15 \mathrm{~min}$ in $0.1 \times \mathrm{SSC}, 0.1 \%$ SDS at $37^{\circ} \mathrm{C}$ and $5 \mathrm{~min}$ in $0.1 \times \mathrm{SSC}, 0.5 \% \mathrm{SDS}$ at $55^{\circ} \mathrm{C}$. Next, blots were dried and exposed to X-ray films (X-Omat, Kodak) for 2-7 days.

Equivalent amounts of RNA were loaded as assessed on the basis of abundance of $18 \mathrm{~S}$ and 28S RNAs and by Northern analysis using a chicken $B$-actin probe (data not shown).

\section{O ocyte injection}

Oocytes were obtained from adult Xenopus laevis by standard procedures (22) and stored immediately in Barth's solution (88 $\mathrm{mM} \mathrm{NaCl}, 1 \mathrm{mM} \mathrm{KCl}, 0.8 \mathrm{mM} \mathrm{MgSO}_{4}, 0.3$ $\mathrm{mM} \mathrm{Ca}\left(\mathrm{NO}_{3}\right)_{2}, 0.4 \mathrm{mM} \mathrm{CaCl} 2,2.4 \mathrm{mM}$ $\mathrm{NaHCO}_{3}, 7.5$ Tris, pH 7.6, $200 \mathrm{mOsm} / \mathrm{kg}$ ) containing penicillin $(9.6 \mu \mathrm{g} / \mathrm{ml})$ and streptomycin $(10 \mu \mathrm{g} / \mathrm{ml})$. The follicular cell layer was removed by incubation with $1 \mathrm{mg} / \mathrm{ml}$ collagenase (type 1A; Sigma) in sterile Barth's solution for $2 \mathrm{~h}$ at $25^{\circ} \mathrm{C}$ with gentle continuous shaking. Oocytes were then 
washed ten times with $10 \mathrm{ml}$ of the same solution and stored overnight at $4{ }^{\circ} \mathrm{C}$ and then used for mRNA microinjection. Selected defolliculated oocytes $(\sim 1.0 \mathrm{~mm}$ in diameter) were injected with $50 \mathrm{nl}$ of water or mRNA ( $1 \mathrm{mg} / \mathrm{ml})$ using an automatic microinjection system. Oocytes were incubated for $72 \mathrm{~h}$ at $18^{\circ} \mathrm{C}$ in Barth's solution with daily changes.

When the sense [5'-TTGCCATGTGCT TCCTGGCTCGTGAGCCCT-3'] or antisense [5'-AGGGCTCACGAGCCAGGA AGCACATGGCAA-3'] AQP3 oligonucleotide derived from the 420-bp RT-PCR product was used, the mixture of each oligonucleotide ( $2.3 \mathrm{ng} /$ oocyte) with mRNA (50 ng/oocyte) was warmed to $65^{\circ} \mathrm{C}$ for $2 \mathrm{~min}$ and allowed to cool at room temperature just before co-injection.

\section{O smotic water permeability}

Experiments were performed in a temperature-jacketed chamber with a curved bottom at $18^{\circ} \mathrm{C}$. An oocyte injected with water or with total mRNA was transferred from 200 mOsm Barth's solution to a chamber containing ten-fold diluted Barth's solution $(20 \mathrm{mOsm})$. The increase in osmotic volume was followed for the first $120 \mathrm{~s}$ by videomicroscopy by storing digitized images at 10-s intervals in a computer. The time-dependent volume change of the oocyte was considered linear for this period of time and the Posm was calculated as previously reported (23).

\section{Solute uptake into oocytes}

Solute uptake into Xenopus laevis oocytes was studied as described (24). Briefly, individual oocytes previously microinjected with water or colon mRNA were incubated in 0.2 $\mathrm{ml}$ Barth's solution containing $100 \mu \mathrm{Ci} / \mathrm{ml}$ $\left[{ }^{3} \mathrm{H}\right]$-glycerol $(200 \mathrm{mCi} / \mathrm{mmol})$ and $2.7 \mu \mathrm{Ci} / \mathrm{ml}$ $\left[{ }^{14} \mathrm{C}\right]$-urea $(8.6 \mathrm{mCi} / \mathrm{mmol}$, New England Nuclear, Boston, MA, USA) and $1 \mathrm{mM}$ urea and glycerol with continuous shaking. The uptake was stopped after 10 min by adding 4 $\mathrm{ml}$ ice-cold Barth's solution and each oocyte was placed on a filter (type GF-A, Whatman) and washed twice with $5 \mathrm{ml}$ of the same solution under vacuum. Then, oocyte and filter were placed in a glass vial with $0.1 \mathrm{ml}$ formic acid for $5 \mathrm{~min}$ and mixed with $5 \mathrm{ml}$ scintillation fluid to determine radioactivity.

\section{Immunoblotting studies}

Human colon was homogenized in 200 $\mathrm{mM}$ sucrose/10 mM Tris-HCl, $\mathrm{pH}$ 7.4, containing leupeptin $(1 \mu \mathrm{g} / \mathrm{ml})$ and $0.1 \mathrm{mg} / \mathrm{ml}$ phenylmethylsulfonyl fluoride. After homogenization in a Potter apparatus and centrifugation at $3,000 \mathrm{~g}$ for $10 \mathrm{~min}$ to remove nuclei and incompletely homogenized membrane fragments, a high-speed pellet was prepared by centrifugation at $100,000 \mathrm{~g}$ for $60 \mathrm{~min}$. Membranes were dissolved in SDS loading buffer, heated to $65^{\circ} \mathrm{C}$ for $5 \mathrm{~min}$, and resolved on $13 \%$ polyacrylamide gel. Proteins were electrotransferred to a nitrocellulose membrane by the semi-dry method. Membranes were blocked with $2 \%(\mathrm{w} / \mathrm{v})$ bovine serum albumin in PBS for $30 \mathrm{~min}$ at room temperature and incubated overnight with the purified anti-AQP3 antibody $(50 \mathrm{ng} / \mathrm{ml})$. The secondary antibody was goat antirabbit IgG conjugated to alkaline phosphatase used at 1:1000 dilution. Sites of antibody-antigen reaction were visualized using 5-bromo-4chloro-3-indolyl phosphate and nitroblue tetrazolium as color development reagents.

\section{Immunocytochemistry}

Fixation and preparation of tissue. For immunocytochemistry, human colonic mucosa was fixed in ice-cold $4 \%$ paraformaldehyde in PBS, dehydrated, and embedded in cytoparaffin. Thin ( $4-5 \mu \mathrm{m})$ consecutive sections were cut on a microtome and placed on microscope slides. For immunofluorescence, human colon was fixed in $4 \%$ paraformalde- 
hyde and cryoprotected overnight with PBS containing $30 \%(\mathrm{w} / \mathrm{v})$ sucrose, embedded in ornithine carbamyl transferase (OCT) compound (Miles Laboratories Inc., Clifton, NJ, USA), and frozen in liquid $\mathrm{N}_{2}$. Cryosections (4-5 $\mu \mathrm{m}$ ) of human colon and rat kidney (control) were placed on the same gelatincoated glass slide.

Immunolabeling of sections. Rabbit affinity-purified polyclonal antibody against a 26-amino acid synthetic peptide, corresponding to the carboxyl terminus of AQP3 $\left(\mathrm{NH}_{2-}\right.$ CHLEQPPPSTEAENVKLAHMKHKEQI$\mathrm{COOH})(25)$ was used.

For immunofluorescence, slides were preincubated with nonimmune goat serum and then incubated with the purified anti-AQP3 antibody $(5 \mu \mathrm{g} / \mathrm{ml})$ overnight at $4^{\circ} \mathrm{C}$. After rinsing, the slides were incubated with fluorescein isothiocyanate-conjugated mouse antirabbit IgG (Sigma Clone RG-96, 1:40) for $4 \mathrm{~h}$ at room temperature. Omission of primary antibody was used as negative control.

For immunolocalization by light microscopy, the sections were incubated with PBS containing $1 \%$ bovine serum albumin for 60 $\mathrm{min}$ at room temperature and then with purified anti-AQP3 antibody (3-7 $\mu \mathrm{g} / \mathrm{ml})$ overnight at $4{ }^{\circ} \mathrm{C}$ in PBS containing $1 \%$ bovine serum albumin. The slides were then rinsed and incubated for $1 \mathrm{~h}$ at $25^{\circ} \mathrm{C}$ with antirabbit IgG biotinylated species-specific whole antibody from donkey (Amersham RPN 1004, Amersham International, Amersham, Buckingham, UK) at a 1:100 dilution followed $1 \mathrm{~h}$ by streptavidin biotinylated horseradish peroxidase complex (Amersham RPN 1051) at 1:100 dilution. The labeling was visualized by reaction with diaminobenzidine containing $\mathrm{NiCl}_{2}(26,27)$. Purified nonspecific rabbit IgG was used as negative control.

\section{Results}

\section{AQ P3 mRNA expression}

A 420-bp RT-PCR product was ampli- fied, cloned and sequenced from adult stomach, jejunum, ileum and colon and from children's colon (Figure 1). This sequence showed $96 \%$ identity to rat kidney AQP3 $(16,28), 98 \%$ identity to human kidney AQP3 (29) and $99 \%$ to human kidney glycerol intrinsic protein (GLIP) (30) in their respective conserved regions. Furthermore, AQP3 mRNA expression in the different gastrointestinal sections was analyzed by Northern blot using the 420-bp RT-PCR product as a probe. A transcript of $2.2 \mathrm{~kb}$ was expressed more abundantly in colon than in jejunum, ileum or stomach (Figure 2).

\section{O smotic water permeability}

To determine the functional expression of AQP3, Posm was measured in Xenopus laevis oocytes injected with total mRNA from the different gastrointestinal sections. The results are summarized in Table 1. For each anatomic region, the Posm corresponding to oocytes injected with water or with mRNA were averaged from different specimens and their average differences from each other were calculated. Only in distal colon from adults and children did the average

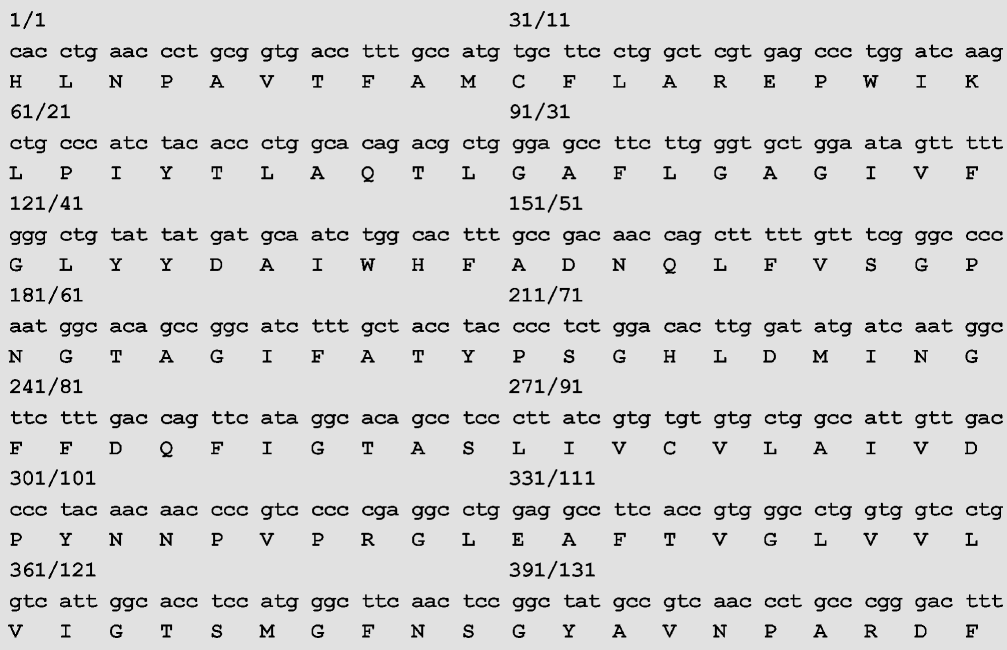

Figure 1 - AQP3 mRNA detection in human colon by RT-PCR. Nucleotide and deduced amino acid sequence of the 420-bp RT-PCR product obtained from human colon. The sequence was the same in all gastrointestinal sections. 
differences significantly differ from zero (Table 1, columns 5 and 6). These differences were inhibited by treatment of oocytes by incubation with $\beta$-mercaptoethanol for 15 min (Figure 3A,B). An antisense but not a sense AQP3 primer co-injected with colon mRNA also inhibited AQP3 expression (Figure $3 \mathrm{~A})$. In addition, oocytes expressing AQP3 exhibited increases in $\left[{ }^{3} \mathrm{H}\right]$-glycerol and $\left[{ }^{14} \mathrm{C}\right]$-urea uptake which were abolished when colon mRNA was co-injected with excess AQP3 antisense primer. In both cases, the AQP3-sense primer was used as control (Figure 4A,B).

\section{Immunolocalization of AQ P3 in human colon}

Figure 5A shows the immunoblot of a crude membrane preparation $(100,000 \mathrm{~g}$ membrane fraction) from human colon probed with the anti-AQP3 antibody. A protein band of $27 \mathrm{kDa}$ was seen and another faint band of higher apparent molecular mass $(35 \mathrm{kDa})$ was also observed. This pattern is

Figure 2 - Northern blot analysis of AQP3 mRNA in the different human gastrointestinal sections. A transcript of $2.2 \mathrm{~kb}$ was expressed more abundantly in coIon than in jejunum, ileum or stomach. Positions of RNA markers are indicated by lines. with $0.3 \mathrm{mM} \mathrm{HgCl}_{2}$ for $10 \mathrm{~min}$ and restored

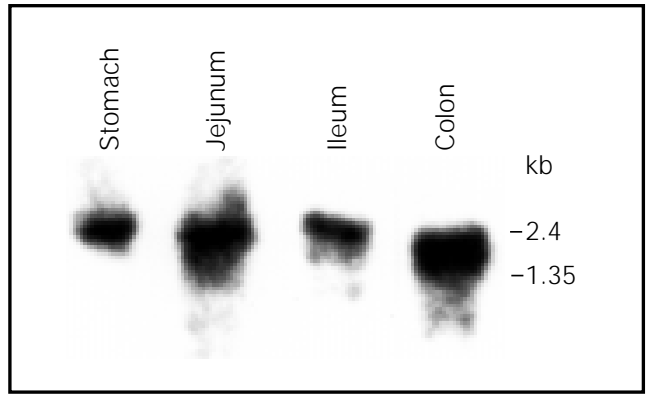

similar to that reported for rat kidney medulla (14) where the upper band represents the glycosylated form of AQP3, and the lower band represents the nonglycosylated form. No bands were detected when nonimmune goat serum was used or when the primary antibody was omitted (data not shown).

Immunofluorescence of human adult colon with AQP3 antibody showed strong staining in villus but not in crypt epithelial cells (Figure 5C) when compared with a negative control (Figure 5B). At high power magnification, the labeling appeared to be localized predominantly in the apical membrane of surface cells while a considerably weaker signal was detected in the basolateral domain of these cells (Figure 5D and $\mathrm{E}$; for control, see Figure 5F). Strong staining in collecting ducts of rat kidney medulla (positive control) is shown in Figure 5G.

Identification of labeling in villus epithelial cells was confirmed with immunoperoxidase staining (Figure 6). At low power magnification intense staining was detected in some of the villus epithelial cells but not in globets cells, and no staining was observed in the crypt epithelial cells (B). Control sections treated with nonimmune $\mathrm{IgG}$ revealed an absence of labeling (A). At high power magnification, strong staining was observed in the apical membrane and the subapical area just beneath the apical membrane of villus epithelial cells (C). Immunolabeling of rat kidney sections revealed la-

Table 1 - Osmotic water permeability (Posm: $\times 10^{-4} \mathrm{~cm} / \mathrm{s}$ ) of Xenopus laevis oocytes.

$\mathrm{N}$ indicates the number of patients. In each case 6 to 12 oocytes were injected with water (control) or with mRNA from each gastrointestinal section.

\begin{tabular}{|c|c|c|c|c|c|}
\hline & \multicolumn{4}{|c|}{ Adults } & \multirow{2}{*}{$\begin{array}{c}\text { Children } \\
\text { Distal colon }\end{array}$} \\
\hline & Stomach & J ejunum & Ileum & Distal colon & \\
\hline mRNA-injected & $13.02 \pm 2.9$ & $16.51 \pm 4.79$ & $8.17 \pm 0.77$ & $18.27 \pm 0.88$ & $24.92 \pm 1.69$ \\
\hline Water-injected (control) & $10.71 \pm 1.66$ & $15.04 \pm 3.51$ & $9.76 \pm 0.97$ & $10.96 \pm 1.05$ & $14.47 \pm 0.35$ \\
\hline Mean difference & $2.31 \pm 1.63$ & $1.46 \pm 1.28$ & $-1.59 \pm 1.72$ & $7.31 \pm 0.67$ & $10.46 \pm 1.34$ \\
\hline t-test & $\mathrm{NS}, \mathrm{N}=3$ & $N S, N=3$ & $N S, N=3$ & $P<0.01, N=5$ & $P<0.05, N=2$ \\
\hline
\end{tabular}


beling in the basolateral membrane domain of collecting duct cells (D).

\section{Discussion}

The functional characteristics of water handling in the gastrointestinal tract has been extensively studied both in vivo and in vitro $(1,4,7)$. Nevertheless, to our knowledge, this is the first study on the functional expression of water channels using total mRNA from different human gastrointestinal regions.

We demonstrate here the expression of functional water channels only when adult and children colon mRNA was injected into Xenopus oocytes but not when mRNA from adult stomach, jejunum or ileum was used. The $\mathrm{HgCl}_{2}$-sensitive expression of colon mRNA was similar to that reported for the other tissues encoding AQPs $(28,31,32)$. The ability of an AQP3 antisense sequence to block the mRNA expression suggests the presence of an AQP3. Increase of urea and glycerol uptake by Xenopus oocytes injected with colon mRNA and its inhibition by AQP3 antisense also support the functional expression of AQP3.

We also reported here an amplification of a 420-bp DNA from stomach, jejunum, ileum and colon using RT-PCR. The amino acid sequence of all DNAs presented a high homology to AQP3 and GLIP, both cloned from a human kidney cDNA library $(29,30)$. Expression of mRNA was demonstrated in all gastrointestinal sections by Northern blot and these results are coincident with those described by Ishibashi et al. (29) and Koyama et al. (33). However, we observed functional AQP3 only in human colon. A possible explanation could be a higher level of AQP3 mRNA in colon than in the other gastrointestinal sections as observed in the Northern blot studies. The lack of water-channel expression in stomach and small intestine is consistent with functional data for vesicles derived from these tissues showing low plasma membrane water permeability $(11,12)$.

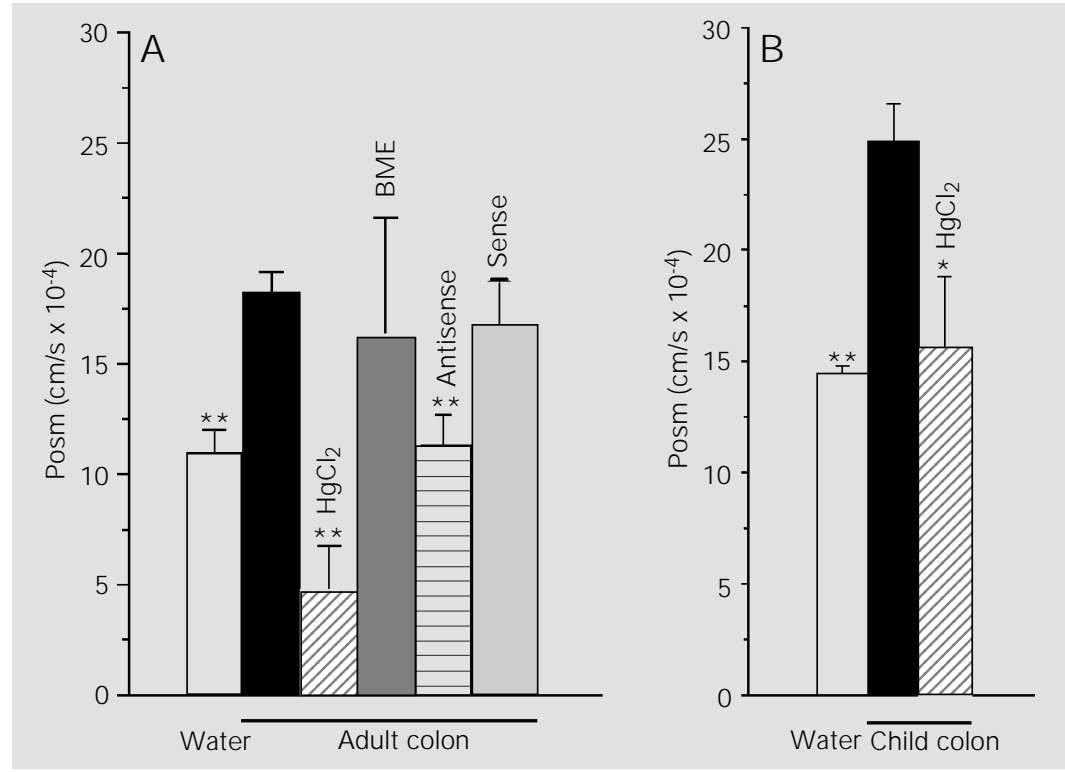

Figure 3 - Functional expression of AQP3 present in human colon. Each bar indicated mean osmotic water permeability (Posm) measured in 6 to 10 oocytes, 3-4 days after injection with water (open bars) or with $50 \mathrm{ng}$ of mRNA with the indicated treatment. A, The assay was performed using mRNA from adult colon with or without $0.3 \mathrm{mM} \mathrm{HgCl} 2$ (5-min incubation), with $\mathrm{HgCl}_{2}$ treatment followed by incubation with ß-mercaptoethanol (BME; 10 $\mathrm{min}$ ) or preceded by incubation with AQP3 oligonucleotide sense or antisense primer (2.3 ng/oocyte). B, Injection of a child distal colon mRNA and its $\mathrm{HgCl}_{2}$ treatment. The Student ttest was applied and data were compared with those for colon mRNA-injected oocytes. $* \mathrm{P}<0.05, * * \mathrm{P}<0.01$, NS $=$ nonsignificant.

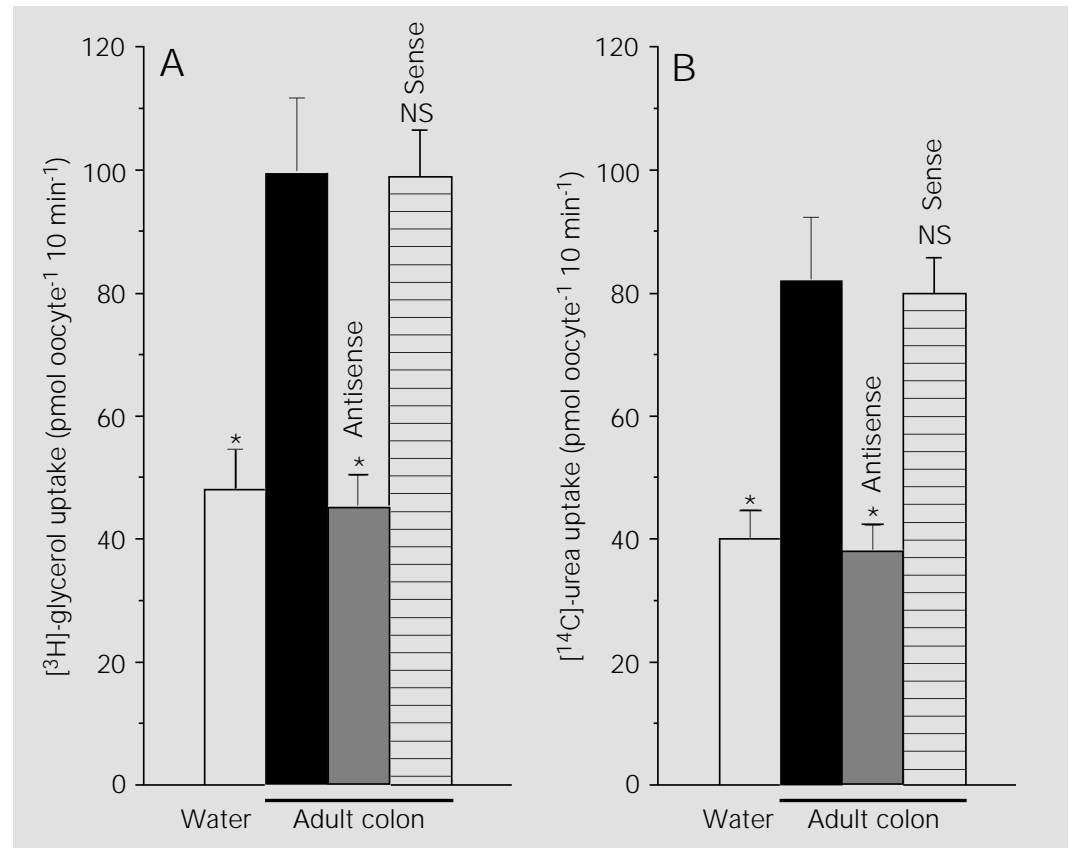

Figure 4 - Selective AQP3 permeability to a small solute. Bars represent the mean \pm SEM uptake of $\left[{ }^{3} \mathrm{H}\right]$-glycerol $(\mathrm{A})$ and $\left[{ }^{14} \mathrm{C}\right]-$ urea $(\mathrm{B})$ measured in 6 to 10 oocytes, 3-4 days after injection with water or with $50 \mathrm{ng}$ of human colon mRNA. AQP3 oligonucleotide sense or antisense primers were co-injected with colon mRNA and data were compared by the Student t-test. $* \mathrm{P}<0.01$ compared to colon mRNA-injected oocytes. NS $=$ nonsignificant. 
Recently, Yamamoto and Sasaki (34) discussed the clear demonstration of AQP3 mRNA expression in stomach and small intestine and the inability to detect AQP3 protein in these epithelial cells by immunohistochemistry and functional studies. Further studies are needed to determine the correla-

A
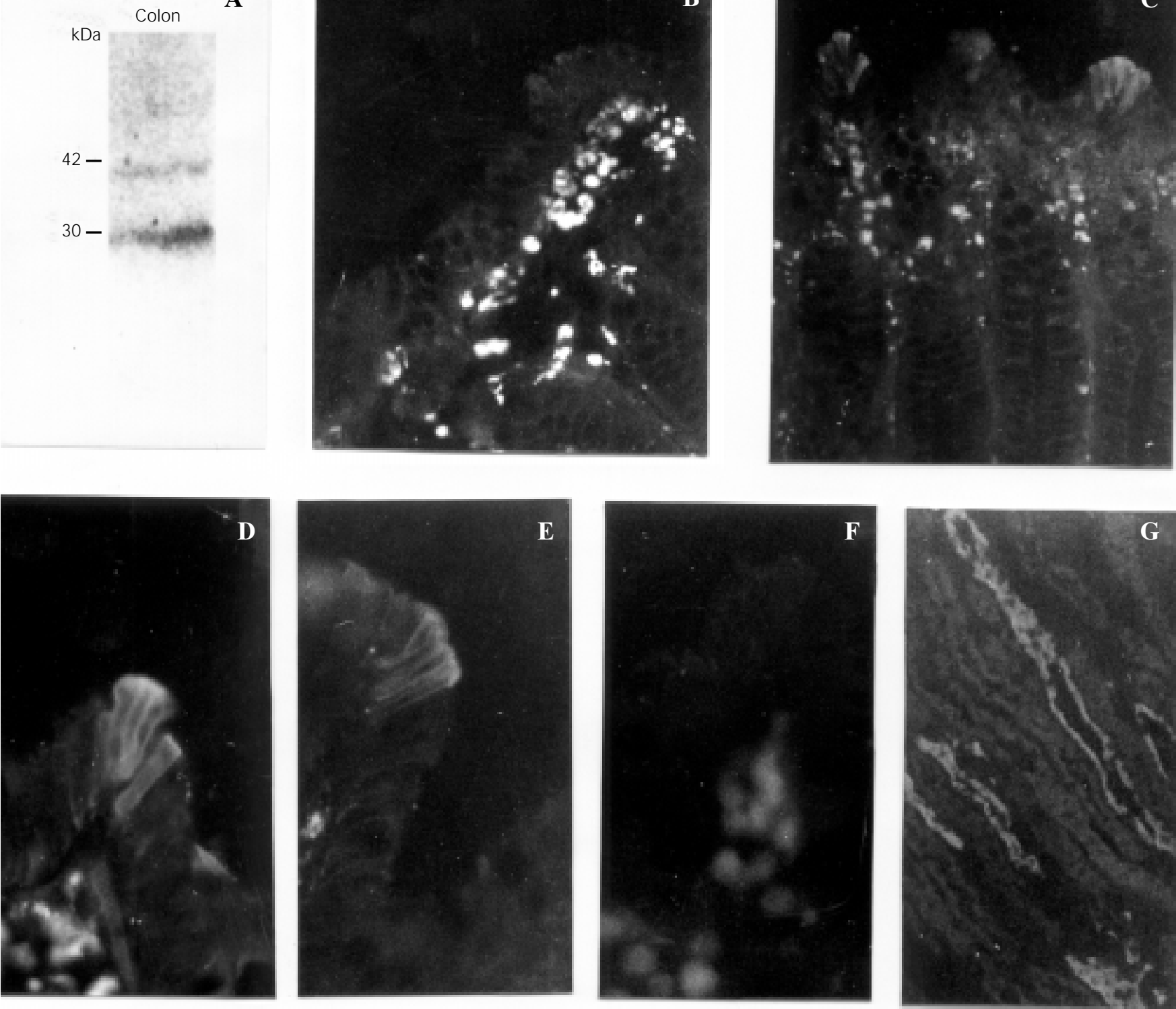

Figure 5 - Immunoblot and immunofluorescence of AQP3 water channel protein in human colon using purified anti-AQP3 polyclonal antibody. Immunoblot of a colonic mucosa homogenate showed two bands, $27 \mathrm{kDa}$ and $35 \mathrm{kDa}$, corresponding to nonglycosylated and glycosylated forms of AQP3 protein, respectively (A). Immunofluorescence localization of AQP3 (C-E) and their control (B: X190, F: X450 magnification). Surface epithelial cells were strongly labeled with anti-AQP3, whereas crypt epithelial cells were unlabeled (C: X190 magnification). Labeling is heavily localized in the apical membrane and weakly localized in the basolateral membrane of villus epithelial cells (D: X375 magnification and E: X450 magnification). Extensive labeling in collecting duct of rat kidney medulla was detected in the positive control (G: X190 magnification). tion between AQP3 mRNA and protein expression.

Immunohistochemistry using anti-AQP3 revealed that $\mathrm{AQP} 3$ labeling is present in the surface epithelial cells of human colon. Labeling of AQP3 was found in the apical and basolateral membranes of villus epithelial

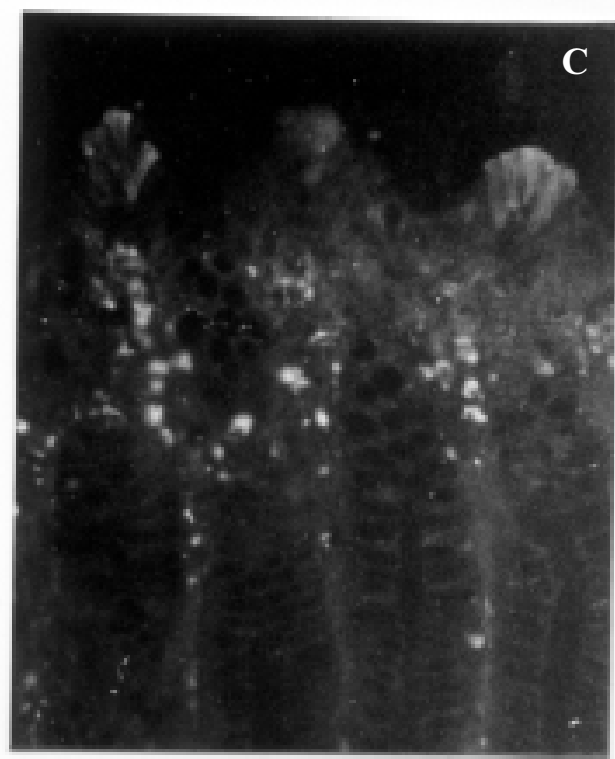


cells. Previous immunolocalization studies have shown expression of GLIP and AQP3 in the basolateral domain of surface epithelial cells in rat colon but not in rat small intestine (14,33).

Thus, we have identified functional AQP3 in the human colon which may be implicated in fluid absorption across this particular in-
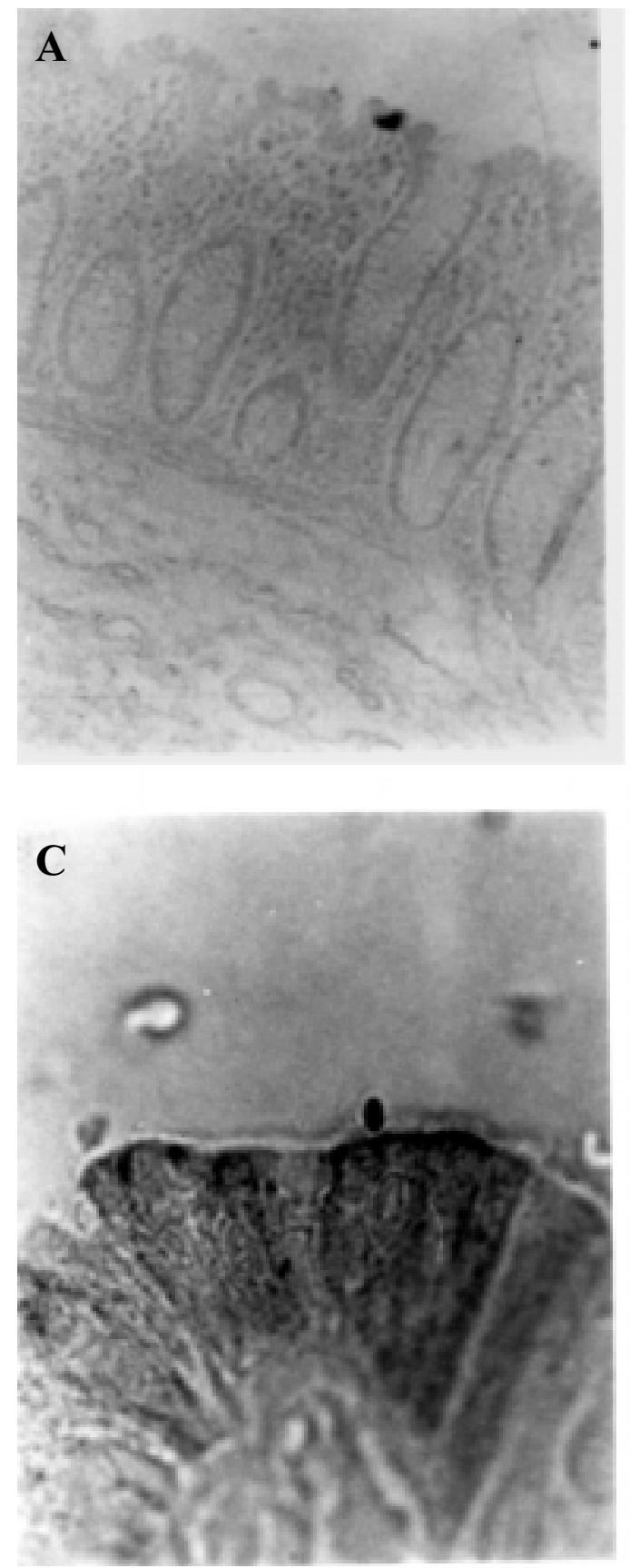

testinal section. The fact that the intercellular junctions of colonic cells were reported to be tight (35) limits water transport across the paracellular route and suggests the transcellular route as the main pathway for the water movement driven by ion absorption. If this is the case, regulation of $\mathrm{AQP} 3$ may contribute to maintaining the control of

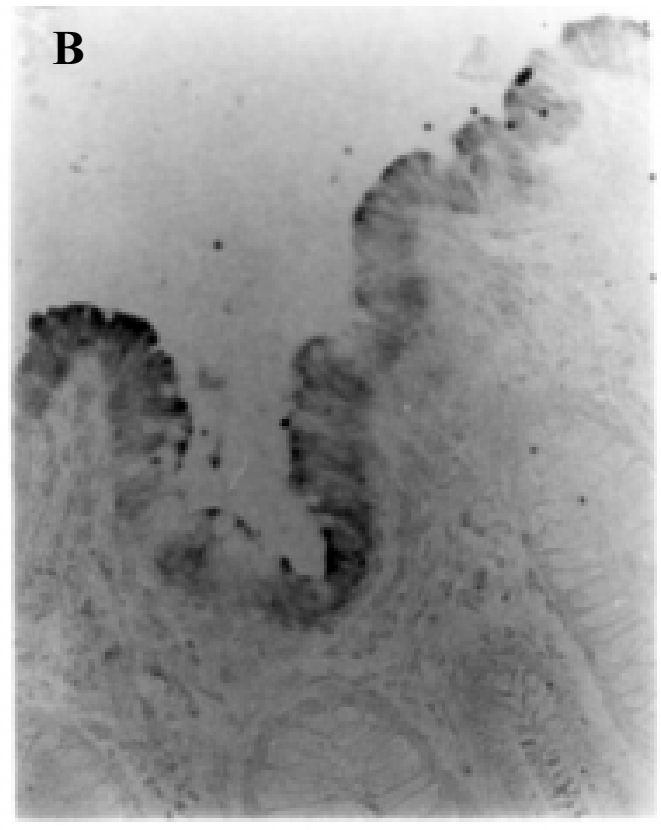

Figure 6 - Immunoperoxidase staining showing AQP3 expression on the colonic surface epithelial cells (B: X230 magnification) and their control (A: X115 magnification). Strong staining was observed in the apical membrane and the subapical region of villus epithelial cells (C: X1150 magnification). Rat kidney sections used as control revealed labeling in the basolateral membrane domain of collecting duct cells (D: X1150 magnification). Replacement of primary antibody with nonimmune IgG revealed absence of labeling ( $A$ : X115 magnification). 
water absorption and its alteration could lead to abnormal states such as constipation and diarrhea.

\section{Acknowledgments}

We gratefully acknowledge the excellent assistance of Mr. Luis Masciotra and Mrs. Silvia Fariña in the immunoperoxidase and immunofluorescence studies. We thank Dr. Alberto Monserrat, Departamento de Patología, Facultad de Medicina, UBA, for advice in histology interpretation, and Dr. Miriam Echevarria, Departamento de Fisio- logía y Biología Animal, Facultad de Farmacia, Universidad de Sevilla, España, for helpful suggestions. We thank Dr. M.A. Knepper, National Institutes of Health, Bethesda, MD, USA, for kindly providing the antibody to aquaporin-3 and for the suggestions concerning the immunoblots. We also thank Dr. Fernando Galindo and Mrs. Estrella Alvarez, Hospital de Gastroenterología "Dr. Bonorino Udaondo", and Drs. Luis Voyer and Graciela Bortolazzo, Hospital de Niños "Dr. Pedro de Elizalde", for providing the gastrointestinal specimens.

\section{References}

1. Binder HJ (1983). Absorption and secretion of water and electrolytes by small and large intestine. In: Sleisenger MH \& Fortran J S (Editors), Gastrointestinal Disease: Pathophysiology, Diagnosis, Management. 3rd edn. WB Saunders, Philadelphia, 811-840.

2. Bennish ML (1994). Cholera: pathophysiology, clinical features and treatments. In: Wachsmuth K, Blake P \& Olsvik O (Editors), Vibrio Cholerae and Cholera: Molecular to Global Perspectives. American Society of Microbiology, Washington, DC, 229-255.

3. Powell DW (1987). Intestinal water and electrolyte transport. In: J ohnson LR (Editor), Physiology of the Gastrointestinal Tract. 2nd edn. Raven Press, New York, 1267-1305.

4. Field M (1993). Intestinal electrolyte secretion: History of a paradigm. Archives of Surgery, 128: 273-278.

5. Singh SK, Binder HJ , Boron WF \& Geibel J P (1995). Fluid absorption in isolated perfused colonic crypts. J ournal of Clinical Investigation, 96: 2373-2379.

6. Escobar E, Galindo F \& Parisi M (1990). Water handling in the human distal colon in vitro: role of $\mathrm{Na}^{+}, \mathrm{Cl}^{-}$and $\mathrm{HCO}_{3}{ }^{-}$. Biochimica et Biophysica Acta, 1027: 257263.

7. Parisi M \& Ibarra C (1996). Aquaporins and water transfer across epithelial barriers. Brazilian J ournal of Medical and Biological Research, 29: 933-939.

8. Agre P, Brown D \& Nielsen S (1995). Aquaporin water channels: unanswered questions and unresolved controversies. Cell Biology, 7: 472-483.

9. Nielsen $S \&$ Agre $P$ (1995). The aquaporin family of water channels in kidney. Kidney International, 48: 1057-1068.

10. Verkman AS, Shi LB, Frigeri A, Hasegawa $H$, Farinas J , Mitra A, Skach W, Brown D, Van Hoek AN \& Ma T (1995). Structure and function of kidney water channels. Kidney International, 48: 1069-1081.

11. Priver NA, Rabon EC \& Zeidel ML (1993). Apical membrane of the gastric cell: water, proton and nonelectrolyte permeabilities. Biochemistry, 32: 2459-2468.

12. Van Heeswijk MPE \& Van Os PH (1986). Osmotic water permeability of brush border and basolateral membrane vesicles from rat cortex and small intestine. J ournal of Membrane Biology, 92: 183-193.

13. Parisi M, Pisam M, Calamita G, Gobin R, Toriano R \& Bourguet J (1995). Water pathways across a reconstituted epithelial barrier formed by Caco-2 cells: effects of medium hypertonicity. J oumal of Membrane Biology, 143: 237-245.

14. Frigeri A, Gropper MA, Turck CW \& Verkman AS (1995). Immunolocalization of the mercurial insensitive water channel and glycerol intrinsic protein in epithelial cell plasma membrane. Proceedings of the National Academy of Sciences, USA, 92: 4328-4331.

15. Hasegawa $H$, Zhang $R$, Dohrman $A \&$ Verkman AS (1993). Tissue-specific expression of mRNA encoding rat kidney water channel CHIP28k by in situ hybridization. American J ournal of Physiology,
264: C237-C245.

16. Ishibashi K, Sasaki S, Fushimi K, Uchida S, Kuwahara M, Saito H, Furukawa T, Nakajima K, Yamaguchi Y, Gojobori T \& Marumo $F$ (1994). Molecular cloning and expression of a member of the aquaporin family with permeability to glycerol and urea in addition to water expressed at the basolateral membrane of kidney collecting duct cells. Proceedings of the National Academy of Sciences, USA, 91: 62696273

17. Koyama $Y$, Yamamoto T, Kondo D, Funak H, Yaoita E, Kawasaki K, Sato N, Hatakeyama K \& Kihara I (1997). Molecular cloning of a new aquaporin from rat pancreas and liver. J ournal of Biological Chemistry, 272: 30329-30333.

18. Ma T, Yang B \& Verkman AS (1997). Cloning of a novel water and urea-permeable aquaporin from mouse expressed strongly in colon, placenta, liver, and heart. Biochemical and Biophysical Research Communications, 241: 53-58.

19. Misaka T, Abe K, Iwabuchi $K$, Kusakabe $Y$, Ichinose M, Miki K, Emori $Y$ \& Arai S (1996). A water channel closely related to rat brain aquaporin 4 is expressed in acidand pepsinogen-secretory cells of human stomach. FEBS Letters, 381: 208-212.

20. Valenti G, Verbavatz JM, Sabolic I, Ausiello DA, Verkman AS \& Brown D (1994). A basolateral CHIP28/MIP26 related protein (BLIP) in kidney principal cells and gastric parietal cells. American J ournal of Physiology, 267: C812-C820.

21. Davis GR, Santa Ana CA, Morawski SG \& 
Fordtran J S (1980). Development of a lavage solution associated with minimal water and electrolyte absorption or secretion. Gastroenterology, 78: 991-995.

22. Dascal N (1987). The use of the Xenopus oocytes for the study of ion channels. CRC Critical Reviews in Biochemistry, 22: 317-373.

23. Capurro C, Ford P, Ibarra C, Ripoche $P$ \& Parisi M (1994). Water permeability properties of the ovarian oocytes from Bufo arenarum and Xenopus laevis. A comparative study. J ournal of Membrane Biology, 138: 151-157.

24. Martial S, Ripoche P \& Ibarra C (1991). Functional expression of urea channels in amphibian oocytes injected with frog urinary bladder mRNA. Biochimica et Biophysica Acta, 1090: 86-90.

25. Ecelbarger CA, Terris J, Frindt G, Echevarria $M$, Marples $D$, Nielsen $S \&$ Knepper M (1995). Aquaporin-3 water channel localization and regulation in rat kidney. American J ournal of Physiology, 269: F663-F672.

26. Hsu SM, Raine L \& Fanger H (1981). Use of avidine-biotin-peroxidase complex $(A B C)$ in immunoperoxidase techniques:
A comparison between $A B C$ and unlabeled antibody (PAP) procedures. J ournal of Histochemistry and Cytochemistry, 29: 577-580.

27. Hsu SM \& Soban E (1982). Color modification of diaminobenzidine (DAB) precipitation by metallic ions and its application for double immunohistochemistry. J ournal of Histochemistry and Cytochemistry, 30: 1079-1082.

28. Echevarria M, Frindt G, Preston G, Milovanovic S, Agre P, Fischbarg J \& Windhager EE (1993). Expression of multiple water channel activities in Xenopus oocytes injected with mRNA from rat kidney. J ournal of General Physiology, 101: 827-841.

29. Ishibashi K, Sasaki S, Saito F, Ikeuchi T \& Marumo F (1995). Structure and chromosomal localization of a human water channel (AQP3) gene. Genomics, 27: 352-355.

30. Ma T, Frigeri $A$, Hasegawa $H \&$ Verkman AS (1994). Cloning of a water channel homolog expressed in brain meningeal cells and kidney collecting duct that functions as a stilbene sensitive glycerol transporter. J ournal of Biological Chemistry, 269: 21845-21849.
31. Sasaki S, Fushimi K, Ishibashi K \& Marumo $F$ (1995). Water channels in the kidney collecting duct. Kidney International, 48: 1082-1087.

32. Zhang $R$, Skach $W$, Hasegawa $H$, Van Hoek AN \& Verkman AS (1993). Cloning, functional analysis and cell localization of a kidney proximal tubule water transporter homologous to CHIP28. Journal of Cell Biology, 120: 359-369.

33. Koyama $Y$, Yamamoto $T$, Tani $T$, Nihei $K$, Kondo D, Funaki H, Yaoita E, Kawasaki K. Sato N, Hatakeyama K \& Kihara I (1999). Expression and localization of aquaporins in rat gastrointestinal tract. American J ournal of Physiology, 276: C621-C627.

34. Yamamoto T\& Sasaki S (1998). Aquaporins in the kidney: Emerging new aspects. Kidney International, 54: 1041-1051.

35. Davis GR, Santa Ana CA, Morawski SG \& Fordtran J S (1982). Permeability characteristics of human jejunum, ileum, proximal colon and distal colon: results of potential difference measurements and unidirectional fluxes. Gastroenterology, 83: 844-850. 